\title{
Determinants of changes in nurses' behaviour after continuing education: a literature review
}

\author{
A.L. Francke MA RN \\ Researher, Helen Dowling Institute for Biopsychosorial Medicine \\ B. Garssen PhD \\ Research coordinator, Helen Dowling Institule for Blopslchosocial Medicine, Rotlerdam \\ and H. Huijer Abu-Saad PhD RN \\ Professor. Department of Nursing Science. Universily of Limburg. Moastricht. \\ The Netherlands
}

FRANCKE A.L.. GARSSEN B. \& HUIJER ABU-SAAD H. (1995) Journal of Advanced

Nursing 21, 371-377

Determinants of changes in nurses' behaviour after continuing education: a literature review

Nursing continuing-education programmes may differ in the extent to which they affect nursing practice. Differences may be explained by characteristics of the participants' background, the programme itself, teacher(s), relationship between participants. relationship between participants and teacher(s), physical environment during the programme, participants' social system. knowledge, skills and attitudes, and intention to change. In this literature review, a model is presented which integrates these variables and which may be used to explain why continuing-education programmes have no, little or considerable effect. On the basis of current scientific knowledge, colleagues" and superiors' support emerges as the most important determinant of behavioural changes in nursing practice.

\section{INTRODUCTION}

A storm of continuing education is sweeping through the nursing profession. The increase in nursing, medical and technical insights has resulted in nurses' diligently enrolling in continuing-education programmes. In addition, the changes in the structure and culture of the delivery system affect the need for continuing education. A total dependence on the medical profession has shifted to a more autonomous position for registered nurses. which required new knowledge, skills, attitudes and behaviour (Oliver 1984. Archer 1983).

In relation to these developments, the authors are studying the effectiveness of a nursing programme entitled 'Pain

Correspondence: A.L. Francke, Researcher. Helen Dowling Instilute. Mathenesserloan 183,3014 HA Rolterdam, The Netherlands. assessment and management in surgical cancer patients' (Francke \& Erkens 1994). In the design phase of this study. it was necessary to answer the question: Under what conditions will this programme have the greatest impact? This formed the background of the literature review presented in this paper.

The intention of nursing continuing education. as espoused by the American Nurses' Association (ANA 1986), is to enhance nursing practice and, consequently. to promote the welfare of patients. Alterations in knowledge, skills and attitudes do not automatically mean changes in practice. Therefore, this literature review only focuses on determinants of behavioural changes.

In respect to our programme. we were primarily interested in determinants of behavioural changes subsequent to programmes on pain assessment or management. Unfortunately. only a few of these programmes have been 


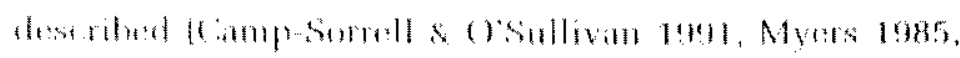

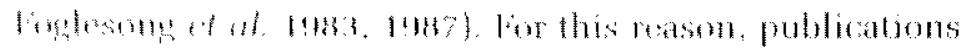

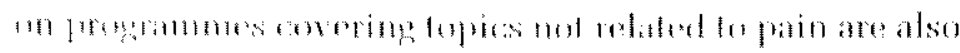

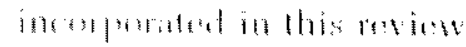

\section{MODFI.}

A trawhat of most studies in tomtinumg eluation is the lath of a conceptual model. This sometimes makes it

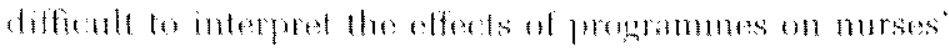


dent variabes in the musing continuing education litera-

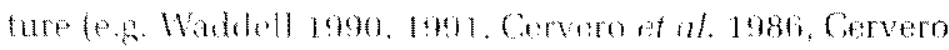
1985 ) and in the patagende literature (es. Botkerts 1991 . Peteron 19>9) that ans retated to behavoural changes, namely thateteristics of the parlicipants bakground, the programme itsolf teacher(s), rolationship between participants and teather(s). relatimship betwen participants, physical environment during the programme and social systen of the participant.

We have also distilled some modiating variables from the continuingetucation liturature (e.g. Kienter \& Hentschel 1989. Cervero et al. 1986. Cervero 1985) and from sociopsychological publications (Ajzen \& Fishbein 1980. Fishbein \& Ajzen 1975. Rogers \& Shoemaker 1971) that appear to play a determinant role in behavioural changes. These variables are: (a) knowledge. skills and attitudes of participants after the programme, and (b) participants intention after the programme to change their behaviour. Wo have integraten these variables in a model (Fignre 1) that can be considered an extension and adaption of Cervero's (1985) model.

In the following sections, we will review the aforementioned variables in relation to behavioural changes.

\section{PARTICIPANTS' BACKGROUND CHARACTERISTICS}

\section{Baseline scores, age and experience}

In Grond \& Visser's (1979) and Pool's (1983) Dutch studies on the effects of a communication programme, participants with little nursing experience reported the most behavioural changes. This phenomenon could be explained by the fact that the young, inexperienced participants had relatively low baseline scores on the outcome variable 'Therapeutic behaviour'. Therefore, changes could be realized more by the younger nurses than by their older colleagues (Pool 1983). In addition, the younger nurses were probahly less set in established behaviour patterns and thus more indined to utilize new skills (see also Cox \& Baker 1981. Foglesong at al. 1987).

However, in her metamanalysis of 34 studies on the effects of nursing continuing-education activities, Waddell (1990, 1991) found no relationship between experience and behavioural changes, nor between age and behavioural changes. Yet it should be mentioned that publications on very different types of programmes were included in Waddell's meta-analysis, which may account for these outcomes.

\section{Education and intelligence}

Wo have found some indications in Rogers \& Shoemaker's (1971) study on the relationship between education level and intelligence-related characteristics, and behavioural changes. Rogers \& Shoemaker examined 1500 studies on innovations and expanded the concept of innovations to such an extent that continuing-education activities can be included. It appeared that individuals with many years of education, high educational aspirations and high intelligence more readily adopted innovations than individuals lacking these qualities.

\section{Motivation}

It can make a difference whether someone enrolls in a programme purely because it is imposed by his or her superiors or policy makers, or because he or she is actually interested. Foglesong et al. (1987) did establish that nurses who voluntarily participated in a pain-management programme applied their new pharmacological insights to a greater extent than nurses who were required to take the programme. In contrast, Ruder (1987) found no differences in behavioural changes between nurses voluntarily participating and nurses compelled to participate in a programme on the nursing process. A problem in the interpretation of these outcomes is that whether or not participation is mandatory does not always clearly indicate the extent to which a participant is motivated.

\section{Figure 1}

Viriblus related to behavioural harge followibs antinting sulution (CE)






\section{Innovativeness and openness to changes}

Cervero et al. (1986) investigated the effects of a programme for recently hired nurses. They found that nurses who were described by their superiors as innovators applind their new knowledge the most, while laggards appliced it the least. The results of Wamuth's (1987) study pointed along the same lines. Six months after the contusion of a COPD (chronic obstructive pulmonary disease) programme. Warmuth asked which factors influenced nurses to apply what they had learned. Openness to changes was most frequently mentioned as an important factor.

These findings are supported by Rogers \& Shoemaker's (1971) study which revealed that individuals with a favourable attitude towards change were earlier adopters of innovations.

\section{Other individual characteristics}

Rogers \& Shoemaker (1971) also concluded that earlier adopters were often characterized by a favourable attitude towards risk, a high degree of social integration and participation, a nonfatalistic attitude, familiarity with innovations, and having a tendency to seek out information.

After a cancer nursing programme, Donovan et al. (1981) asked nurses what kept them from applying what they had learned. Lack of self-confidence and difficulty in taking initiative were stated as the most prominent inhibiting factors.

\section{CHARACTERISTICS OF THE PROGRAMME}

\section{Content}

In her meta-analysis, Waddell $(1990,1991)$ made the following divisions in respect to the content of the 34 programmes studied: general nursing practice, specialty nusing practice, advanced nursing practice, chronic disease, medication/pharmacology, and new graduate orientation. Waddell did not find a relationship between the content of the programmes and the effect size of behavioural changes.

\section{Quality}

Warmuth (1987) asked nurses who participated in a COPD programme what stimulated them to utilize their new knowledge and skills. The high quality of the programme was stated relatively often. Waddell $(1990,1991)$ assigned in her meta-analysis a quality rating to each of the $34 \mathrm{con}$ tinuing-education activities, with respect to: duration of the programme, presence of a needs assessment, specificity of objectives, teaching methods, inclusion of the principles of adult learning, extent to which the ANA definition (ANA 1986) of continuing education was met, use of quali-


tives. Combrey to expostations, them did net apfese to bes a rolationship betwen the quality ratimg and the effort sizes with respect to behavioural changess.

Waddoll's own explanation for this mutrome was that tho publications on which the motanalysis was besed probably did unt give a correct description of he activities concerned. Another explanation is that a valid description of quality could not be obtained whthout laking palicipants' subjective perception of the quality of a proserame into account.

\section{Educational methods}

Methods which pay attention to both affective and cognitive learning. for example 'confluent education' (Francke \& Erkens 1984), would have a greater impact on behavioural changes than purely cognitive-oriented methods (Alexander 1990). A controlled health education study by Ross Paulk (1985) suggested that methods that focus both on affections and knowledge have a greater effect on behaviour than methods that focus only on knowledge. With respect to nursing continuing education. controlled studies concerning this topic are lacking.

Several authors, for instance Partitt (1989) and Popiel (1977), pointed to the importance of student-directed methods for nursing (continuing) education. In these methods, students have considerable influence on how. when and what is learned. Unfortunately, there is no known nursing continuing-education study that addresses the question of whether student-directed methods do in fact have a greater impact than teacher-directed mothods on behavioural changes.

\section{Educational strategies}

In Waddell's meta-analysis $(1990,1991)$, the influence of more specific educational strategies. like live classroom instruction, lectures and group discussions, was investigated. Waddell could not find any relationship between these educational strategies and the effect size of behavioural changes. When interpreting these findings, it should not be forgotten that in this meta-analysis publications on very different types of programmes were included. which means we must be cautious in drawing conclusions.

\section{Duration}

Frequently, it is emphasized that behavioural changes should not be expected when programmes are ol short duration ( 8 hours or less) and when many different topics are discussed (Camp-Sorrell \& O'Sullivan 1991. Ferrell 1988. Oliver 1984, Cox \& Baker 1981). Still. Waddell's metaanalysis (1990, 1991) did not show a relationship between the length of programmes and the effect size of behavioural 


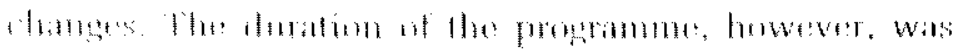



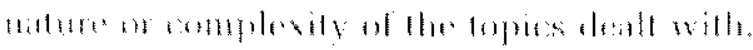

\section{Follow-up}

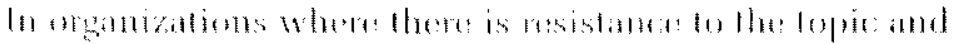

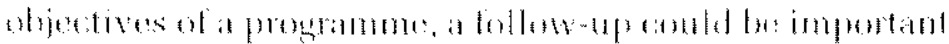

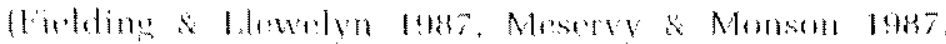

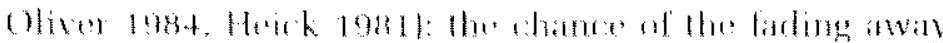
af what has heen learned would be reduced. A follow-up cin take varions forms. tor example, practical supervision (Alesery \& Monson 1987), follow-up meetings (Oliver 1984. Heick 1981) or comsultations between participants (lideling L Lowelyn 1967). We only found empirical data on this subject in Wake's (1987) review. Wake analysed I mursing continuing-education studies and found that six of the seren effective programmes (programmes with an impact on practicel, and none of the four ineffective programmes, hat some kind of follow-up.

\section{Target group}

It is often suggested that the target group must be homogenous, in terms of protessional background and learning objectives and needs le.g. Ferrell 1988. Pool 1983. Heick 1981). However, it appears from Waddell's meta-analysis (1990. 1991) that programmes exclusively ained at qualified nurses did not lead to more behavioural changes than those also oriented towards nursing students. nursing aids or other health care workers.

It did appear. however. from Waddells meta-analysis that when participants came from the same institution more bohavioural changes were demonstrated than when participants came from different institutions. An explanation for this finding could be that participants in the former instance may be geared more to the specifio needs and problems occurring in their institution. (For other pussible explanations. see the sections Relationship between participants' and 'Social support'.)

\section{Other characteristics of the programme}

Rogers \& Shoemaker (1971) described the following five characteristics related to adoption of imnovations: relative advantage (the degree to which an innovation is perceived as better than the idea it supersedes) compatibility (the degree to which an innovation is perceived as consistent with the existing values, past experiences. and needs of the receiverl; complexity the degree to which an innovation is relatively simple to understand and utilize); trablatity the degree to which an innovation mav be seperimented with on a limited basis): and observability (the degree to which the results of an innovation are visible wothers)
What applies to innovations in general will most likely alst apply to continuing-education activities. Accordingly, various researchers (Ferrell 1988. Fielding \& Llewelyn 1447, Cervero 1985, Cervero \& Rottet 1984, Heick 1981 , (inx \& Baker 1981) indicate that a programme must be relatul to the monls of nurses and the objectives of the organization (comparable with Rogers \& Shoomaker's rela live advanlage and compatibility). Others (Wake 1987 Kellner 1983. Pool 1983) emphasize the importance ol pratical applicability (comparable with Rogers \& Shoumaktr's romplexity and trialability). However, 'hard' restarch data on the intluence of such characteristics on nurses behaviour are lacking

\section{CHAR ACTERISTICS OF THE TEACHER(S) AND THEIR RELATIONSHIP WITH PARTICIPANTS}

Research by Rogers Eason \& Webb Corbett (1991) revealed that nurses prefer warm, enthusiastic, friendly teachers with a great deal of expertise. We have some empirical indications concerning the influence of the teacher's expertise on nurses' behavioural changes. In the pragramme Pool (1983) studied, teachers (psychologists) were fairly unfamiliar with nursing practice. Pool suggested that the lack of changes in practice was related to the teachers' general approach which fitted poorly with the nurses' direct working experiences.

\section{Characteristics of the relationship between participants}

It is known from pedagogical studies that reciprocal sympathy and support. respect and feedback among students contribute to a favourable course of the learning process (Boekaerts 1987). The extent to which participants' interactions affect behavioural changes has not been entirely established. Yet we do have some indications. As already mentioned. Waddell's meta-analysis $(1990,1991)$ showed that programmes in which participants all came from the same institution were the most effective. This may be an indication that the relationship between participants is an important factor.

\section{Characteristics of the physical environment}

According to Quinn (1980), room temperature, regular breaks and the availability of refreshments may help increase motivation during nursing education. Empirical data supporting a relationship between such variables and the extent to which nurses change their behaviour after a programme are still lacking. 


\section{CHARACTERISTICS OF THE SOCIAL SYSTEM}

\section{Social support}

In Pools (1983) programme, murse partiojumbls experi. enced disapproval, envy and lack of understanding lrom colleggues and superiors. This inhibited application of the communication skills learned. A large number of authors report similar findings (Brasler 1993. Suitor Soheller 1993. Waddell 1990, Kiener \& Hentschel 1989, Brown ef al. 1987. Fielding \& Llewelyn 1987. Wake 1987. Warmuth 1987. Cervero 1985, Kelmer 1983. Donovan et al. 1981, Heick 1981. Ajzen \& Fishbein 1980. Valencius 1980. Rogers \& Shoenaker 1971).

In institutions where nurses are encouraged to apply new knowledge and skills. this seems to have favourable consequences. Peden et al. (1990) studied the effects of a continuing-education programme on patient education. Two months after conclusion of the programme, participants themselves, as well as their supervisors. reported positive behavioural changes. The researchers linked this to the fact that participants felt encouraged by others in the organization. Cox \& Baker (1981) also established that nurses who received compliments and support from their superiors frequently and increasingly applied the new communication and diagnostic skills. In Meservy \& Monson's (1987) study it was found that physicians' support as well may have a large impact on the utilization of new skills.

As mentioned before. Waddell (1990, 1991) found that programmes that drew participants from a single institution resulted in more behavioural changes than programmes that drew participants from various institutions. One possible explanation for this difference could be that, after the single-institution programmes, participants will receive relatively more support and reinforcenent from colleagues than after the multiple-institution programmes.

\section{Climate and setting}

Utilization of new knowledge and skills may be directly related to the climate of the institution in general. and the climate of the work unit in particular (Suitor Scheller 1993). The value structure. informal and formal goal structures, norms, roles, hierarchies, sanctions and rewards of an organization can interfere with the transfer of knowledge to the work setting (Suitor Scheller 1993. Cervero 1985, Rogers \& Shoemaker 1971). Yet no experimental studies have been conducted that provide a strong basis for these statements.

Some authors, e.g. Foglesong et al. (1987), have suggested that the climate in academic hospitals is characterized by more openness to education and changes in practice than that in nonacademic hospitals. In Waddell's meta-analysis (1900, 1901), however. mo restionship wes

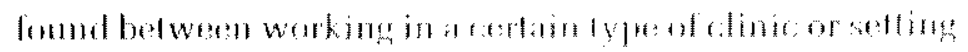
atud behaviourat changes.

\section{Practical conditions and support}

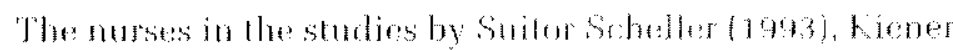
\&. Hentsolnel (1989), Pool (1983) and Donovan ot al (1931) cited lack of time and personmel as significant reasons lor nol applying new knowledge and skills. To what oxtent these factors were actual reasons and not rationalizations, has not been examined vot. Howover, Cox \& Baker (1981) suggested that practical conditions have to be created to facilitate leaming and use of new knowledge and skills. For example, the deployment of extra nursing personnel during and shorly after a programme would sometimes be necessary to give participants the opportunity to put learning into practice.

\section{Area}

Waddell $(1990,1991)$ divided the various areas of practice into general medical/surgical, maternal/child health. psychiatric/mental health, critical care, and gerontology. There was no significant difference in effect sizes in behavioural change across these areas of practice.

\section{Nursing system}

According to Foglesong et $a l .11987$ ) and Pool (1983), taskoriented nursing systems may inhibit, while patientoriented systems may facilitate, the utilization of certain skills. Here, too, controlled studies are lacking.

\section{KNOWLEDGE, SKILLS AND ATTITUDES AFTER THE PROGRAMME}

Knowledge. skills and attitudes are immediate determinants of nurses' behavioural changes (Warmuth 1987). Kiener \& Hentschel (1989) asked 443 nurses, who had participated in programmes focused on writing skills or on nursing theories, to list factors that inhibit or facilitate behavioural changes. Newly acquired knowledge was most often mentioned as a facilitating lactor

Concerning the relationship between skills and behayioural changes, empirical data can be derived from Brown ef al. (1987). In this sudy about a progranme in physical assessment, the most frequently cited reason for lack of behavioural changes was that nurses did not feel competent enough with their skills.

With respect to the relationship between attitudes and behavioural changes. information is given in the sociops chological literature on 'reasoned action' (Ajzen 1988. Ajzen \& Fishbein 1980. Fishbein \& Ajzen 1975). Whether someone has a positive, neutral or negative attifule 


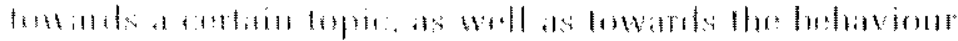



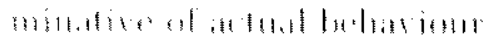

\section{Intention lo change after the programme:}

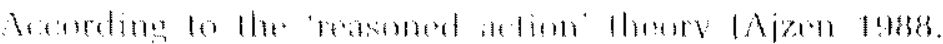





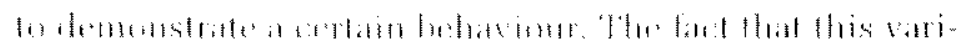

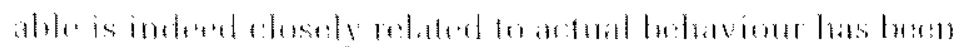

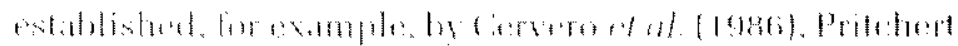

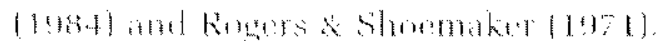

\section{RECOMIENDATIONS FOR RESEARCH}

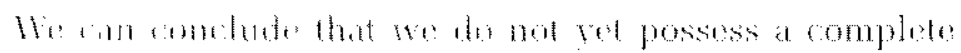
phe ture of the inthene of many aribbles. For example. mor. insight most be gand in the motent to whirh motivatim prow to a programme affects behavioural changes. This is an interesting subien besaust it offers many practcal implations: the question adn be answered whether it

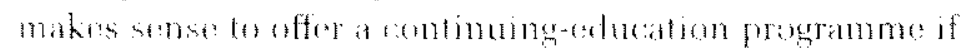
farticipants sem to have little motivation or interest. At this times. with the many discussions about the value of mandatory contiming eluation. this is a relevant theme.

In adtition. it would be worthwhe to focms in future resarch on the inthence of different teaching methods. Fir : wmple, is there a ditfrenor in atfectiveness between


ads? Are teathing methods that stimulate the sharing of persomal aperiences, attitudes and fotings more offective than purely rogntive-orifnted methods? Answers to such questions comb also contribute to the development of thenrs and practice of nursing continuing-education activities

Furthermore, it is a challenge to do research on the intuence of haracteristics of the teacher(s), the participant-teacher relationship and the relationship between participants. For example the question can be answered whether it is important to experience gond contact with the teather and fellow participants with regards to behavicural changes land not onty with regards to general. human reasonsl?

\section{CONCLUSION}

Combmumatucation resenth in nursing is still in its infancy and, consequently, there are still many questions I. Hrimestered Still, we alruaty have indications for the infuence of at least some valables. Particularly, there are cmenlerable data on the inturence of colledgues and superiors support te.s. Cervoro 1985, Cox \& Baker 1981. Rogers \& Shomaker 1971). Therefore, it seems important

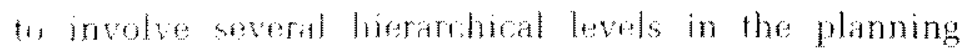

anl implomentation of a continuing-education activity (Waddell 1990). so that participants will have as broad a support base as possible.

In anr programme (Francke \& Erkens 1994), for example, wo fried to involve the nursing directors as well as the warel nurses in mogotiations about the planning of the programme. Furthermore, it appears to be important that colleagues participato together in a course (Waddell 1990. 19911. For this reason, it was decided to implement our programmo in nursing teams, inchuding the head nurse, from the same: ward. This would probably facilitate mutual sulporl amb reinforcement.

\section{References}

Ajzen 1. (1948) Attitudes. Personality, and Behavjour. Open llniversily Press, Milton Koynes.

Apen I. \& Fishbein M. 1980$)$ Understanding Attitudes and Predicting Social Behowiour. Prentice Hall, Englewood Cliffs. New letsey.

Alcxander M.A. (1990) Evaluation of a training program in breast catum nursing. foumal of Continuing Educotion in Nursing 21. $260-266$.

American Nurscs' Association (1986) Manual for Accreditation as an Approter of Continuing Educotion in Nursing. ANA Kansas City.

Aroher H.M. (1983) A study of the impact of ce on occupational health nursing pratice. Occupational Health Nursing 31. $15-23$

Boekants M. (1987) Pstchologie van de Leerling en het Leterprores. Dekker an Van der Vegt. Nijmegen.

Buekands M. (1991) Gedragsterandering en Onderwis. State University Laiden

Braster M.E. (1993) Prefictors af rlinical performance of new graduate nursus participating in preceptor orientation programs. fournal of Continuing Education in Nursing 24(4). $158-165$.

Brown G.I. (1990) Human Teaching for Human Learning: An Introduction to Confuent Educotion. Gestalt fournal, New York.

Brown M.C. Brown J.D. \& Bayer M.M. (1987) Changing nursing practice through continuing education in physical assessment: perceived barriers to implementation. Journal of Continuing Eduration in Nursing 18(4). 111-115.

Camp-Sorrell D. \& OSullivan P. (1991) Effects of continuing education. Pain assessment and documentation. Concer Nursing 14. $49-54$

Cervero R.M. (1985) Continuing professional education and behavioral changt: a model for research and evaluation. Journal of Continuing Education in Nursing 16(3), 85-88.

Cervero R.M \& Rottet S. (1984) Analyzing the effectiveness of continuing professional education: an exploratory study. Adul Education Quarterly 34(3). 135-146.

Cervero R.M., Rottet S. D Dimmock K.H. (1986) Analyzing the effectiveness of continuing education at the workplace. Adult Education Quarterly 36, 78-85.

Cox C.L. \& Baker M.G. (1981) Evaluation: the key to accountability in continuing education. Journol of Continuing Educotion in Nursing 12, 11-19. 
Donovan M., Wolpert P. \& Yasko ). (1981) Gaps and contrants. Nursing Outlook 29, 467-471.

Fernell M.). (1988) The relationship of continuing education offer ings to self-reported change in behavior. Joumal of Confinumg Education in Nursing 19, 21-24.

Fielding R.G. \& Llewelyn S.P. (1987) Communication training in mursing may damage your health and enllusiasm: some warn. ings. Journal of Adranced Nursing 12, $281-290$.

Fishbein M. \& Ajzen I. (1975) Belief. Attitude. Intrution and Behovior. An Introduction to Theory and Reserarch. AddisonWesley, Menlo Park, California.

Foglesong D.H. (1983) the impact of a slaff development offering on nursing practice. Journol of Continuing Eduration in Nursing $14[6], 12-15$.

Foglesong D.H., Lambert J. \& Lmeriak 1. (1987) Variables which influence the effect of staff development on nursing practice. loumal of Continuing Education in Nursing 18, 168-171.

Francke A.L. \& Erkens T. (1994) Confluent education: an integrative approach for nursing (continuing) education. Journal of Adronced Nursing 19(2), 354-361.

Grond P.J.N. \& Visser A.Ph. (1979) Therapeutisch gedrag van verpleegkundigen en het effect van een gesprekstraining. Tijdschrift roor Ziekenterpleging 32, 307-315.

Heick M.A. (1981) Continuing education impact evaluation. Journal of Continuing Education 12(4), 15-23

Keltner M.L. (1983) The perceived impact of continuing education on the practice of nurses working in acute care facilities. Western Journal of Nursing Research 5. 21-40.

Kiener M.E. \& Hentschel D. (1989) What happens to learning when the workshop is over? Ioumal of Continuing Education in Nursing 20[5], 206-211.

Meservy D. \& Monson M.A. (1987) Impact of continuing education on nursing practice and quality of patient care. Journol of Continuing Education in Nursing 18, 214-220.

Myers J. (1985) Cancer pain: assessment of nurses' knowledge and attitudes. Oncology Nursing Forum 12, 62-66.

Oliver S.K. (1984) The effects of continuing education on the clinical behaviour of nurses. Iournal of Continuing Educhtion in Nursing 15. 130-134.

Parfit B.A. (1989) A practical approach to creative teaching: an experiment. Journal of Advanced Nursing 14. 665-677.

Peden A.R. Rose H. \& Smith M. (1990) Transfer of continuing education to practice: testing an evaluation model. Journol of Continuing Education in Nursing 21, 68-72

Peterson P.L. (1979) Direct instruction reconsidered. In Research

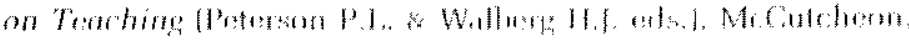
Berkitloy, Californiat, pp, $57-69$.



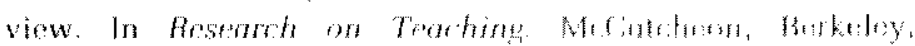
Califormia. ple. $1-27$.

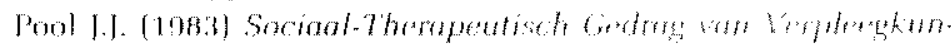


an Vitgeverij. Amsterdim

Popiel E.S. (ed.) (1977) Nursing and the Process af Continumb Educhion 2nd edn. C.V. Mosby, st Louis

Pritchert J.W. (1984) Outcomes of a diabetes prolessionat adu. cation seminar. Diabetus Eduntor 9, 37-39.

Quino F. (1980) The Principles and Proctice of Nurse Education. Croom Helm, Beckenham, Kent.

Rogers E.M. \& Shoemaker F.F. (1971) Communiration of Innovations. The Free Press, New York.

Rogers Eason F. \& Webb Corhet R. (1901) Effective teacher characteristics identified by adult leamers in nursing. Joumal of Continuing Eduration in Nursing 22(1), 21-23.

Ross Paulk J. (1985) Comparison of the effects of confluent vs traditional contraceptive education on young people's knowledge. attitudes and behaviors. Unpublished dissertation. University of California. Santa Barbara.

Ruder S.K. (1987) The comparison of mandatory and voluntary participation in continuing education on nursing performance. PhD Dissertation. Northern Illinois University. Dissertation Abstrocts International 49, 187 A.

Suitor Scheller M.K. (1993) A qualitative analysis of factors in the work environment that influence nurses' use of knowledge gained from ce programs. Journal of Continuing Eduration in Nursing 24(3). 114-122.

Valencius J. (1980) Impact of a continuing education program in cancer nursing. Part 2: Results affecting the learner. Journal of Continuing Education in Nursing 11, 22-28.

Warddell D.L. (1990) The effects of continuing education on nursing practice: a meta-analysis. Dissertation. Universily of Georgia. Unpublished PhD.

Waddell D.L. (1991) The effects of continuing education on nursing practice: a meta-analysis, fournal of Confinuing Education in Nursing 22, 164-168.

Wake M. (1987) Effective instruction in continuing nursing cducation. Journal of Continuing Education in Nursing 18. $188-192$.

Warmuth J.F. (1987) In search of the impact of continuing education. Journal of Continuing Education in Nursing 18(1). 4-7. 
This document is a scanned copy of a printed document. No warranty is given about the accuracy of the copy. Users should refer to the original published version of the material. 